\title{
Endocrine factors in the control of nutrient utilization: ruminants
}

\section{By J. M. BASSETT, Nuffield Institute for Medical Research, University of Oxford, Headington, Oxford $\mathrm{OX}_{3} 9 D S$}

The principal function of hormonal regulation of metabolic homoeostasis is to preserve constancy in the supply of glucose, the major fuel used by the neural control tissues of the body. With recognition of the extensive endocrine regulatory mechanisms of the gastrointestinal tract and their integration with neural reflex mechanisms it is becoming increasingly apparent that anticipatory mechanisms regulating the rate of digestion and entry of metabolites into the general circulation represent an area for endocrine regulation of nutrient homoeostasis which may ultimately turn out to be as significant for homoeostatic regulation as the better known endocrine mechanisms regulating the distribution of nutrients and their utilization by the various tissues of the body (Unger \& Dobbs, 1978).

The evolutionary modification of the ruminant forestomach to permit digestion of herbage cellulose results in major alterations in the metabolites presented for absorption or further digestion lower in the intestines and the consequence that little or no glucose is derived directly from dietary carbohydrate, microbial fermentation in the rumen resulting in its conversion to volatile fatty acids (VFA). There is no evidence for similar major alterations in mechanisms regulating metabolic homoeostasis. However, the role of gut endocrine mechanisms in ruminants remains almost totally unexplored at present. The possibility that there are modifications to the endocrinology of the foregut should not be ignored.

Although acetate is a major substrate for metabolism in many peripheral tissues of ruminants after weaning (Ballard et al. 1969 ) glucose remains the principal fuel for oxidative metabolism in the central nervous system (Lindsay \& Setchell, r 976). It is also a major substrate for the pregnant uterus (Setchell et al. 1972; Prior \& Christenson, 1978) and lactating mammary gland (Bergman \& Hogue, 1967).

Hormonal regulation of glucose homoeostasis therefore remains central to metabolic regulation and it appears that most of the hormonal alterations observed in ruminants in different physiological situations can be related to the need for maintenance of glucose homoeostasis. While problems associated with failure of the mechanisms regulating disposal of excessive dietary carbohydrate are so common in man they are virtually unheard of in ruminants. However, the high productivity demanded of domesticated ruminant species leads to a number of problems apparently resulting initially from overtaxing of their glucose supply mechanisms. The hormonal processes governing the supply of glucose precursors and gluconeogenesis are therefore of particular significance in relation to ruminant metabolic regulation and any consideration of how nutrient utilization is regulated. Quantitative aspects of glucose metabolism in ruminants (Leng, 1970; Bergman, 
1975) and intermediary metabolism in relation to ketosis (Baird, 1977) have been reviewed. The present review will discuss the relevance for nutrient utilization and metabolic homoeostasis of the hormone responses to nutrient ingestion in ruminants.

\section{Insulin}

There can be little question that insulin remains at the centre of metabolic homoeostasis in ruminants despite the lack of a dietary source of glucose after weaning. Their often quoted insensitivity to the hypoglycaemic action of insulin (Reid, 1952) is misleading. Insulin lack, brought about either by pancreatectomy or alloxan administration, results in a diabetic condition as severe as that in other species leading to impaired utilization of glucose, acetate, and $\beta$ hydroxybutyrate, to free fatty acid mobilization and, if untreated, to acute ketoacidosis and death (Reid et al. 1963; Jarrett $e t$ al. 1 972). The negligible use of glucose for lipogenesis in ruminant tissues may be the principal reason for their insensitivity to insulin (see review by Bauman \& Davies, 1975). However, adipose tissue utilization of both glucose and acetate can be stimulated by insulin (Skarda \& Bartos, I969; Yang \& Baldwin, 1973; Mears \& Mendel, 1974) and there can be little question about the important antilipolytic action of insulin in vivo (Jarrett et al. 1972; Bassett, unpublished observations) despite inconclusive in vitro observations (Bauman \& Davies, 1975). Mean plasma insulin concentrations in sheep fed ad lib. on a wide range of forage diets are positively related to digestible organic matter and protein intakes (Bassett et al. 1971), as also are glucose entry rates (Leng, 1970). Yet plasma glucose concentrations bear little or no relation to either dietary intake or plasma insulin concentration. The close correlation between plasma insulin and glucose turnover rate in these studies (Bassett $e$ t al. 1971 illustrates clearly the important concept that insulin is a major regulator of glucose disposal, and probably of anabolic metabolism in general, in ruminants, even though the plasma glucose concentration itself may not be an important determinant of insulin secretion. The responses of plasma insulin in ruminants fed once or twice daily are also consistent with the view that insulin determines glucose turnover, but plasma glucose concentration plays little part in regulating the insulin secretory response to ingested nutrients (Bassett, 1975; Battacharya \& Alulu, 1975; Evans et al. 1975; Chase, Wangsness, Kavanaugh et al. 1977; Trenkle, 1978). Insulin secretion is markedly stimulated by feeding, the increase being greater with concentrate than with hay diets. However, it is still not clear whether the difference is simply a function of the digestible nutrient intake or reflects difference in the pattern of ruminal VFA production. Hepatic glucose output and glucose turnover increase after feeding (Katz \& Bergman, 1969; Thompson et al. 1978), but because plasma glucose rarely rises and also because the insulin rise is often coincident with the rise in plasma VFA, considerable attention has been given to the possibility that increased plasma VFA cause the postprandial stimulation of insulin secretion. However, although in vivo and in vitro studies show that propionate, butyrate and valerate will stimulate insulin release from ruminant pancreas, acetate, the 
principal VFA of peripheral blood does not (Manns \& Boda, 1967; Manns, Boda \& Willes, r967; Horino et al. 1968). It remains controversial whether the low, albeit increased, concentrations of propionate or other stimulatory VFA, present in peripheral plasma are responsible for the postprandial rise in insulin release (Bassett, 1975; Trenkle, 1978). Observations on the very early changes in insulin after feeding (Bassett, 1974a) drew attention to the involvement of reflex vagal stimulation and the importance of this has been confirmed in more recent studies with cattle (Chase et al. 1977; Chase, Wangsness \& Martin, 1977) and sheep (Bassett, unpublished observations). However, the possible involvement of an entero-pancreatic axis in ruminants remains unexplored. Stimulatory effects of crude pancreozymin preparations on insulin release (Baile et al. 1969; Trenkle, 1972; Porter \& Bassett, unpublished observations) point to the possible involvement of gastric inhibitory peptide (an impurity of such preparations) but there is no information about the physiology in ruminants of this gut hormone apparently largely responsible for the entero-insular axis in other species (Brown et al. 1975).

While insulin clearly plays an important role in regulating anabolic metabolism in ruminants the tissues in which insulin-stimulated utilization of glucose occurs and their quantitative importance remain undefined. Studies of hind limb metabolism in sheep (Jarrett et al. 1976) suggest that most glucose is returned to the blood as lactate except during exercise, but no studies on the effects of high insulin levels on utilization of glucose or other metabolites such as acetate have been reported.

In ruminants as in other species where insulin release is stimulated by mechanisms other than hyperglycaemia, it is essential that hepatic glucose output be maintained if hypoglycaemia is to be avoided. In the immediate postprandial period and in animals with high intakes of digestible nutrients there is of course a readily available supply of gluconeogenic precursors in the form of propionate and glucogenic amino acids from the diet or subsequent digestion of microbial protein. However, insulin, in addition to its peripheral actions, has marked inhibitory effects on gluconeogenesis and the output of glucose from the liver. While definitive data on the quantitative actions of insulin on ruminant liver glucose metabolism are required it is evident from several investigations that insulin and high glucose concentrations, presumably stimulating insulin release, markedly decrease hepatic glucose output (West \& Passey, 1967; Prior \& Christenson, 1978). It is therefore likely that the high insulin concentrations in the early postprandial period may act to minimize the conversion to glucose of amino acids and propionate. This action of insulin is either offset by the secretion of counterregulatory hormones or by substrate supply since gluconeogenesis and hepatic glucose output are highest in the early postprandial period (Katz \& Bergman, 1969; Thompson et al. 1978). However, the balance between the effects of insulin and counter-regulatory hormones is clearly critical since continuous intravenous infusion into fed wether sheep of $0.02 \mathrm{U}$ insulin/min $(30 \mathrm{U} / \mathrm{d})$ for $3 \mathrm{~d}$ resulted in profound hypoglycaemia and infusion of $0.01 \mathrm{U} / \mathrm{min}$, a rate little higher than 
reported insulin production rates in fed sheep (Brockman \& Bergman, 1975 Trenkle, 1978) caused significant depression in plasma glucose (Bassett, unpublished observations). Glucagon is probably the principal hormone balancing the effects of insulin on glucose metabolism in the liver, maintaining the hepatic conversion of gluconeogenic precursors to glucose while permitting anabolic effects of insulin on peripheral protein and fat metabolism to be maximized.

\section{Glucagon}

The administration of glucagon to sheep results in increased hepatic glucose output and hyperglycaemia, effects which are exaggerated in the insulin-treated alloxan-diabetic animal where a concommitant increase in insulin secretion is absent (Bassett, 1971; Brockman \& Bergman, 1975b; Brockman et al. 1975). Further, glucagon deficiency brought about by infusion of somatostatin decreases hepatic glucose output and plasma glucose concentration in alloxan-diabetic sheep (Brockman \& Johnson, 1977). Similarly hyperglycaemia, glycosuria and protein catabolism are greater in alloxan-diabetic sheep, where glucagon secretion is maintained, than in depancreatized animals (Jarrett, 1969 ). The role of glucagon in maintaining hepatic glucose output is achieved through stimulatory effects on glycogenolysis and gluconeogenesis. Uptake and coversion to glucose of lactate, amino acids and propionate are all increased by glucagon in sheep (Brockman et al. 1975; Brockman, 1978).

Glucagon secretion in sheep is suppressed by hyperglycaemia but stimulated by hypoglycaemia and catecholamines (Bassett, 1973; Brockman et al. 1975; Arcus et al. 1976). Observations on glucagon secretion in adult cattle are lacking, but studies on young calves indicate its importance in hepatic glucose regulation (Edwards \& Bloom, 1978). In sheep fed once daily plasma pancreatic glucagon increased after the meal at the same time as insulin and then declined during a subsequent $3 \mathrm{~d}$ fast (Bassett, 1973). This postprandial increase in glucagon maintains a roughly constant ratio between insulin and glucagon apparently preserving hepatic glucose output in the face of increased insulin secretion (Bassett, 1975). As with insulin, the VFA may be implicated in this postprandial release since VFA in vivo (Bassett, 1973; Bryce et al. 1975; Arcus et al. 1976) and in vitro (Bassett, unpublished observations) stimulate glucagon release from the sheep pancreas. Casein hydrolysates, or L-amino acid mixtures given by abomasal infusion, amino acids given intravenously or in an in vitro system also stimulate glucagon release from sheep pancreas (Bryce et al. 1975; Arcus et al. 1976; Bassett, 1977; Madill \& Bassett, unpublished observations). Although plasma amino acids do not increase after feeding in sheep (Bassett, 1975) protein and amino acids in the gut may influence the entero-insular axis.

Gut hormones can stimulate glucagon release in other species (Dupré, 1978), so the involvement of an entero-insular axis cannot be ignored. In addition, Bloom et al. (1975) have demonstrated that an early, apparently reflex, release of glucagon occurs in the young calf drinking milk. A similar reflex release of glucagon has not been reported in adult ruminants. Although it appears that increased glucagon 
release after a meal may be the way in which inhibitory effects of insulin on hepatic glucose output and the rate of gluconeogenesis are countered, far more information about changes in plasma pancreatic glucagon concentrations and their effect on hepatic glucose output in ruminants is needed to confirm this conclusion and to determine whether increases in insulin and glucagon always occur together when nutrient influx is modified.

Felig et al. (1976) consider that glucagon has only evanescent effects on hepatic glucose output in man and experimental animals, although this is not universally accepted (Unger \& Dobbs, 1978). In ruminants and in other species dependent on gluconeogenesis for their glucose supply this seems unlikely. Glucagon must have a continuing stimulatory effect on hepatic glucose output if hypoglycaemia is to be avoided.

Thus insulin and glucagon, through their inter-related secretion and widespread actions dominate the regulation of carbohydrate metabolism and organic metabolism as a whole in ruminants as in other species. To an extent it appears that glucose utilization may be dictated by the mechanisms regulating insulin and glucagon release rather than by the direct availability of glucose or glucose precursors.

\section{Other hormones influencing nutrient utilization}

While insulin and glucagon appear to be the principal hormones involved in minute by minute regulation of metabolism and nutrient utilization, the role of other hormones with longer term effects on metabolism and which may alter the sensitivity of the system to insulin and glucagon cannot be ignored. Catecholamines, cortisol, thyroid hormones and growth hormone (GH), among a growing number of others, all participate. However, only GH of these appears to show any clear changes in secretion associated with varying nutritional state (see reviews by Bassett, I 975 and Trenkle, 1978). GH secretion in ruminants is clearly episodic (Bassett, 1974b; Trenkle, 1978) but it has been possible to show clearly in sheep and cattle that food ingestion suppresses GH release and that plasma GH concentrations are negatively related to nutrient intake and to plasma insulin concentration (Bassett et al. 1971; Hove \& Blom, 1973; Bassett, 1974b; Blom, Halse et al. 1976). The mechanisms regulating GH release and the function of this hormone remain ill defined. However, its positive association with plasma FFA concentration, despite apparent suppressive effects of FFA on GH release (Hertelendy \& Kipnis, 1973) suggest that the hormone may be concerned more with antagonism of glucose utilization and promotion of lipolysis as observed in acute studies (Bassett \& Wallace, 1966) than in regulation of anabolic metabolism. Hyperglycaemia, hyperinsulinaemia and antagonism of insulin action are features in sheep of prolonged administration of both GH and cortisol, but effects of the two hormones on nitrogen metabolism are completely opposite, GH improving and cortisol worsening nitrogen balance (Wallace \& Bassett, 1966; Bassett \& Wallace, 1967; Bassett, Wallace \& Wheatley, unpublished observations). However, no studies with physiological concentrations of $\mathrm{GH}$ have been undertaken to establish 
the function of variations in its secretion related to nutritional status. Such studies could be of considerable value since marked changes in GH release occur during late pregnancy and lactation.

\section{Physiological state and the endocrine control of metabolism}

While insulin, glucagon and GH appear to regulate the utilization of nutrients in ruminants their secretion and action are clearly modified by the prevailing physiological situation. During exercise or exposure to cold the balance between insulin and glucagon may readily be altered by increased catecholamine secretion since the catecholamines are potent inhibitors of insulin and stimulators of glucagon secretion (Bassett, 1970; Bassett, 1973). In pregnancy and lactation the increased utilization of glucose by the pregnant uterus and the mammary gland clearly modifies the pattern of nutrient utilization and its endocrine regulation (Hove \& Blom, 1976; Blom, Hove et al. 1976; Prior \& Christenson, 1976; Prior \& Christenson, 1978; Hart et al. 1975), changes in plasma insulin and GH concentrations appearing to be of particular importance although their regulation remains obscure. Regulation of nutrient utilization in these situations is considered in more detail elsewhere in the symposium.

\section{Conclusion}

This review has concentrated principally on the role of insulin and glucagon in regulating the flux of glucose in ruminants for although VFA are quantitatively important contributors to oxidative metabolism, glucose homoeostasis remains at the centre of metabolic regulation. The ability to produce additional glucose may well limit productivity in several situations. However, additional information about the relative changes in insulin and glucagon concentrations and their effects on conversion of gluconeogenic precursors to glucose during pregnancy and lactation is needed to determine their importance in controlling glucose supply and thereby production in these situations. Clues already exist that the nervous system and gut endocrine secretions may influence the endocrine pancreas. However, much extra information about these mechanisms, their effects on substrate supply to the liver and on endocrine pancreas secretion in ruminants is required if we are to understand how precursor supply and hormone balance can be manipulated to improve ruminant productivity.

\section{REFERENCES}

Arcus, A. C., Ellis, M. J., Kirk, R. D., Beavan, D. W., Donald, R. A., Hart, D. S., Holland, G. W. \& Redekopp, C. (1976). Aust. F. biol. Sci. 29, 223.

Baile, C. A., Glick, Z. \& Mayer, J. (1969). I. Dairy Sci. 54, 513 .

Baird, G. D. (1977). Biochem. Soc. Trans. 5, 819.

Ballard, F. J., Hanson, R. W. \& Kronfeld, D. S. (r969). Fedn Proc. Fedn Am. Socs exp. Biol. 28, 218.

Bassett, J. M. (1970). Aust. F. biol. Sci. 23, 903.

Bassett, J. M. (1971). Aust. F. biol. Sci. 24, 31 I. 
Bassett, J. M. (1973). Aust. F. biol. Sci. 25, 1277.

Bassett, J. M. (1974a). Aust. F. biol. Sci. 27, 157.

Bassett, J. M. (1974b). Aust. F. biol. Sci. 27, 167.

Bassett, J. M. (1975). In Digestion and metabolism in the ruminant, p. $3^{89}$. [I. W. McDonald and A. C. I. Warner, editors]. Armidale: University of New England Publishing Unit.

Bassett, J. M. (1977). Ann. de Rech. Vet. 8, 362.

Bassett, J. M. \& Wallace, A. L. C. (1966). Metabolism 15, 95.

Bassett, J. M. \& Wallace, A. L. C. (1967). Diabetes 16, 566.

Bassett, J. M., Weston, R. H. \& Hogan, J. P. (1971). Aust. J. biol. Sci. $24,321$.

Battacharya, A. N. \& Alulu, M. (1975). J. Anim. Sci. 41, 225.

Bauman, D. E. \& Davis, C. L. (1975). In Digestion and metabolism in the ruminant, p. 496. [I. W. McDonald and A. C. I. Warner, editors]. Armidale: University of New England Publishing Unit.

Bergman, E. N. (1975). In Digestion and metabolism in the ruminant, p. 292. [I. W. McDonald and A. C. I. Warner, editors]. Armidale: University of New England Publishing Unit.

Bergman, E. N. \& Hogue, D. E. (1967). Am. F. Physiol. $213,1378$.

Blom, A. K., Halse, K. \& Hove, K. (1976). Acta Endocr. 82, $75^{8}$.

Blom, A. K., Hove, K. \& Nedkvitne, J. J. (1976). Acta Endocr. 82, 553.

Bloom, S. R., Edwards, A. N., Hardy, R. N., Malinowska, K. W. \& Silver, M. (1975). J. Physiol., Lond. $253,135$.

Brockman, R. P. (1978). Fedn Proc. Fedn Am. Socs exp. Biol. 37, 339.

Brockman, R. P. \& Bergman, E. N. (1975a). Am. Y. Physiol. 228, 1627.

Brockman, R. P. \& Bergman, E. N. (1975b). Am. J. Physiol. 229, 1338.

Brockman, R. P., Bergman, E. N., Joo, P. K. \& Manns, J. G. (1975). Am. J. Physiol. 229, 1344.

Brockman, R. P. \& Johnson, M. R. (1977). Can. F. Anim. Sci. 57, 177.

Brown, J. C., Dryburgh, J. R., Ross, S. A. \& Dupré, J. (1975). Rec. Prog. Horm. Res. 31, 487.

Bryce, D., Yeh, M., Funderburk, C., Todd, H. \& Hertelendy, F. (1975). Diabetes 24, 842.

Chase, L. E., Wangsness, P. J., Kavanaugh, J. F., Griel, L. C. \& Gahagan, J. H. (1977). F. Dairy Sci. 60, 403 .

Chase, L. E., Wangsness, P. J. \& Martin, R. J. (1977). Y. Dairy Sci. 60, 410.

Dupré, J. (1978). In Gut hormones, p. 303. [S. R. Bloom, editor]. Edinburgh: Churchill Livingstone.

Edwards, A. V. \& Bloom, S. R. (1978). In Gut hormones, p. 394. [S. R. Bloom, editor]. Edinburgh: Churchill Livingstone.

Evans, E., Buchanan-Smith, J. G. \& Macleod, G. K. (1975). F. Anim. Sci. 41, 4474.

Felig, P., Wahren, J., Sherwin, R. \& Hendler, R. (1976). Diabetes 25, rogr.

Hart, I. C., Bines, J. A., Balch, C. C. \& Cowie, A. T. (1975). Life Sci. 16, 1285.

Hertelendy, F. \& Kipnis, D. M. (1973). Endocrinology 92, 402.

Horino, M., Machlin, L. J., Hertelendy, F. \& Kipnis, D. M. (1968). Endocrinology 83, 118.

Hove, K. \& Blom, A. K. (1973). Acta Endocr. 73, 289.

Hove, K. \& Blom, A. K. (1976). Acta Endocr. 82, 544.

Jarrett, I. G. (1969). In Progress in Endocrinology, p. 176. [G. Gual and F. J. G. Ebling, editors]. Amsterdam: Exerpta Med. Int. Cong. Ser. 184.

Jarrett, I. G., Filsell, O. H. \& Ballard, F. J. (1972). Horm. Met. Res. Suppl. 4, i I 1.

Jarrett, I. G., Filsell, O. H. \& Ballard, F. J. (1976). Metabolism 25, 523.

Katz, M. L. \& Bergman, E. N. (1969). Am. Y. Physiol. 216, 953.

Leng, R. A. (1970). Adr. vet. Sci. Comp. Med. 14, 209.

Lindsay, D. B. \& Setchell, B. P. (1976). F. Physiol., Lond. 259, 801.

Manns, J. G. \& Boda, J. M. (1967). Am. F. Physiol. 212, 747.

Manns, J. G., Boda, J. M. \& Willes, R. F. (1967). Am. F. Physiol. 212, 756.

Mears, J. G. \& Mendel, V. E. (1974). F. Physiol., Lond. 240, 625.

Prior, R. L. \& Christenson, R. K. (1976). f. Anim. Sci. 43, I114.

Prior, R. L. \& Christenson, R. K. (1978). F. Anim. Sci. 46, 201.

Reid, R. L. (1952). Aust. F. agric. Res. 3, 160.

Reid, R. L., Hinks, N. T'. \& Mills, S. C. (1963). F. Endocr. 27 , r.

Setchell, B. P., Bassett, J. M., Hinks, N. T. \& Graham, N. McC. (1972). Q. fl exp. Physiol. 57, 257.

Skarda, J. \& Bartos, S. (1969). 7. Endocr. 44, 115.

Thompson, G. E., Bassett, J. M. \& Bell, A. W. (1978). Br. J. Nutr. 39, 219.

Trenkle, A. (1972). J. Dairy Sci. 55, 1200.

Trenkle, A. (1978). F. Dairy Sicı. 6r, $28 \mathrm{I}$. 
Unger, R. H. \& Dobbs, R. E. (1978). A. Rev. Physiol. 40, 307.

Wallace, A. L. C. \& Bassett, J. M. (1 966). Metabolism 15, 95.

West, C. E. \& Passey, R. F. (1967). Biochem. F. 102, 58.

Yang, Y. T. \& Baldwin, R. L. (1973). f. Dairy Sci. 56, 350. 